\title{
Score Another One for the Internet? The Role of the Networked Public Sphere in the U.S. Net Neutrality Policy Debate
}

\section{Citation}

Yochai Benkler, Robert Faris, Hal Roberts, Bruce Etling \& Dalia Othman, Score Another One for the Internet? The Role of the Networked Public Sphere in the U.S. Net Neutrality Policy Debate (Berkman Ctr. Res. Pub. No. 2015-4, Feb. 10, 2015).

\section{Published Version}

https://cyber.law.harvard.edu/sites/cyber.law.harvard.edu/

files/2015_02_10_Score_Another_One_for_the_Internet_0.pdf

\section{Permanent link}

http://nrs.harvard.edu/urn-3:HUL.InstRepos:15858413

\section{Terms of Use}

This article was downloaded from Harvard University's DASH repository, and is made available under the terms and conditions applicable to Other Posted Material, as set forth at http:// nrs.harvard.edu/urn-3:HUL.InstRepos:dash.current.terms-of-use\#LAA

\section{Share Your Story}

The Harvard community has made this article openly available.

Please share how this access benefits you. Submit a story.

Accessibility 

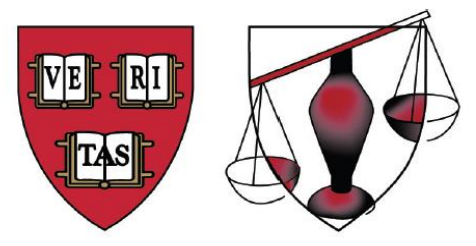

\title{
Berkman
}

The Berkman Center for Internet \& Society

at Harvard University

Score Another One for the Internet?

The Role of the Networked Public Sphere in the U.S. Net Neutrality Policy Debate

\author{
Robert Faris \\ Hal Roberts \\ Bruce Etling \\ Dalia Othman \\ Yochai Benkler
}




\section{Score Another One for the Internet? The Role of the Networked Public Sphere in the U.S. Net Neutrality Policy Debate}

Robert Faris, Hal Roberts, Bruce Etling, Dalia Othman, and Yochai Benkler

February 2015

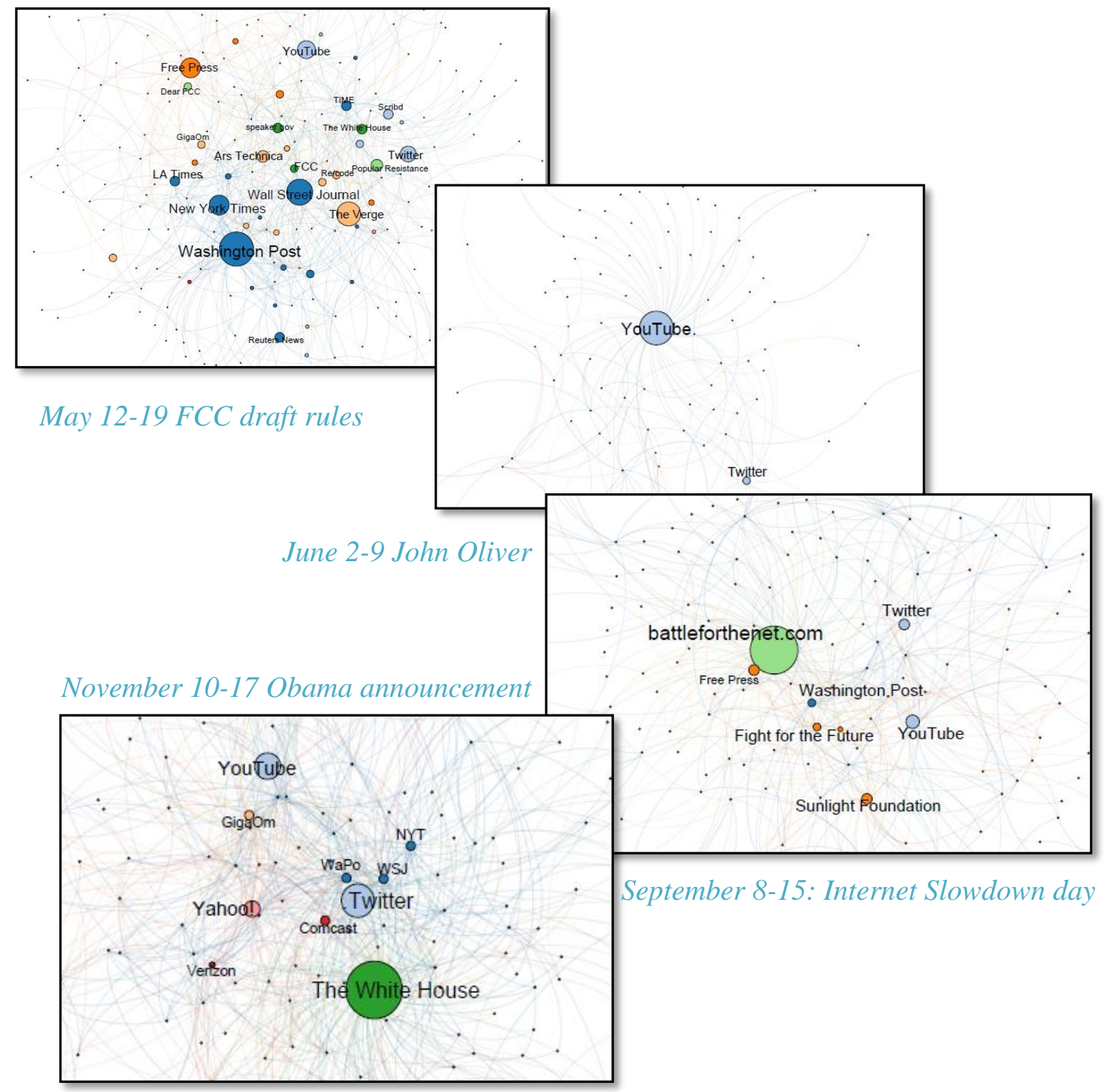




\section{Acknowledgments}

This paper would not have been possible without the efforts and support of many others. David Larochelle and Linas Valiukas helped to build the Media Cloud platform and continue to develop and maintain its technical infrastructure. Amar Ashar has helped to coordinate the overall Media Cloud enterprise over the past several years and contributed to the development of this paper. Sands Fish and Whitney Erin Boesel offered substantive feedback and assistance in the realization of this study. Rebekah Heacock contributed to the research, editing, and layout.

Our friends and collaborators at the Center for Civic Media, led by Ethan Zuckerman, have played a foundational role in working with the Media Cloud team at the Berkman Center to develop the tools and methods used for this project. Their active participation and support has been instrumental in producing this study.

The Media Cloud team offers our thanks to the leadership of the Berkman Center, in particular Jonathan Zittrain, Urs Gasser, and the faculty board of directors, for their continued support and guidance. We are particularly grateful to the Ford Foundation and the Open Society Foundation for their generous support of this research and of the development of the Media Cloud platform.

\section{About Media Cloud}

Media Cloud, a joint project of the Berkman Center for Internet \& Society at Harvard University and the Center for Civic Media at MIT, is an open source, open data platform that allows researchers to answer complex quantitative and qualitative questions about the content of online media. Using Media Cloud, academic researchers, journalism critics, and interested citizens can examine what media sources cover which stories, what language different media outlets use in conjunction with different stories, and how stories spread from one media outlet to another.

http://www.mediacloud.org/ 


\section{Abstract}

In this paper we study the public debate over net neutrality in the United States from January through November 2014. We compiled, mapped, and analyzed over 16,000 stories published on net neutrality, augmented by data from Twitter, bit.ly, and Google Trends. Using a mixed-methods approach that combines link analysis with qualitative content analysis, we describe the evolution of the debate over time and assess the role, reach, and influence of different media sources and advocacy groups in setting the agenda, framing the debate, and mobilizing collective action. We conclude that a diverse set of actors working in conjunction through the networked public sphere played a central, arguably decisive, role in turning around the Federal Communications Commission policy on net neutrality. 


\section{Introduction}

On February $4^{\text {th }}$, the chairman of the Federal Communications Commission (FCC), Tom Wheeler, announced one of the more unlikely political victories Americans have seen in a long time. ${ }^{1}$ Wheeler wrote that he would circulate new net neutrality rules that would reclassify broadband providers as telecommunications carriers, which would place the FCC's jurisdiction over Internet access services on a firmer footing than it has been in over a decade. This is a momentous decision. A year ago, few serious observers of Internet policy would have seen this as much more than a pipe dream for Internet activists. Later in the month, the five FCC commissioners will formally vote on these new net neutrality rules.

This ruling will begin the next stage in what has been a long battle between telecommunications companies and those who seek greater government authority to intervene when needed to ensure an open Internet. Telecommunication companies have successfully fought over the past decade to minimize government regulation of Internet infrastructure by significantly narrowing the FCC's jurisdictional authority over broadband services. The FCC's decision to reclassify broadband as a telecommunications service appears to be a watershed.

In this paper, we track the evolution of the net neutrality debate in digital media from January through President Obama's November 2014 announcement of his direct support for reclassification, an announcement that marked the turning of the political tide in the debate. We conclude that the networked public sphere played a central, arguably decisive, role in turning around the Federal Communications Commission policy on net neutrality. The digitally-mediated social mobilization efforts by Internet policy advocates and coverage of net neutrality by non-traditional media sources combined to produce a large public response that was overwhelmingly in favor of strong net neutrality regulations. Unlike earlier instances of successful online mobilization, which focused on the easier task of stopping a proposed action in a veto-rich environment, the net neutrality debate is the first major example of a successful campaign to achieve an affirmative rule change in the teeth of well-organized lobbying opposition.

We see that one part of the media dynamics around this controversy follows the contours of a traditional public policy debate. The mainstream media informs the public of major developments by government and political figures and offers perspectives from key representatives of the various sides of the issue. However, this debate was also strongly influenced by more recent entrants into the media ecosystem that display many of the same characteristics that were so prominently displayed in the digital media coverage

\footnotetext{
${ }^{1}$ http://www.wired.com/2015/02/fcc-chairman-wheeler-net-neutrality/
} 
and social mobilization efforts opposed to the Stop Online Piracy Act (SOPA) and the PROTECT IP ACT (PIPA), a notable prior example of the impact of the networked public sphere on collective action. ${ }^{2}$ In this debate we see different segments of the media landscape playing significantly different roles. Twitter in particular appears to have been used as a vehicle for social mobilization by proponents of more assertive action in favor of net neutrality, while much of the attention of the broader link economy was directed at the key voices that shaped the debate, including policy makers, reporters, Internet policy experts, corporations, commentators, and advocates.

We show in this paper that the networked public sphere weighed decisively in favor of net neutrality and helped to organize social mobilization efforts and demonstrate public sentiment in favor of governmental action. Opposition to net neutrality in the networked public sphere failed to gain traction. This strong verdict in digital media aligns with the unprecedented volume of public comments, a majority of which backed strong net neutrality rules. This public outpouring exerted undeniable though difficult to measure pressure on the FCC in its deliberations, and likely interacted in a similarly difficult to measure way with President Obama's decision to declare his support for reclassification, a declaration that was a critical moment in the politics of net neutrality.

\section{Methods}

The analysis and observations in this paper are based on several sources of data, analytical approaches, and perspectives on digital media. First, this paper draws on data collected and analyzed using Media Cloud, a platform developed for the collection and analysis of digital media. We identified just over 16,000 stories during the eleven-month period and look at the connections between media sources formed by the more than 10,000 links between these stories. ${ }^{3}$ Tracking the link economy offers a detailed view of the interests and attention of the active participants in the debate, and in aggregate, a measure of the most influential sources and stories. Second, we track the evolution of the debate on Twitter. We gathered data on tweet volume over the course of the debate using the Crimson Hexagon platform. In addition, we tallied the number of times different media stories and resources were shared over Twitter during this

\footnotetext{
2 The Stop Online Piracy Act (SOPA) was a United States House of Representatives bill intended to expand enforcement of copyright infringement online. Following online protests in January 2012, Congress declined to move forward with SOPA or the Senate version of the bill, the Protect IP Act (PIPA). See Benkler et al. for a detailed analysis of the controversy: http://mediacloud.org/2013/07/25/mapping-the-sopa-pipa-debate/

${ }^{3}$ Further details on this methodology and the Media Cloud platform can be found at: http://mediacloud.org/category/blog/tool-blog/
} 
time period based on data collected using Twitter's API. Third, we collected data from the bit.ly API in order to calculate the number of times each of the stories was clicked. This offers a useful proxy of interest and attention among a wider population of readers. Fourth, we collected data from Google Trends to gauge the variation in search volume over time. This provides a measure of the magnitude of general public interest in net neutrality over the course of the debate. Finally, for each of these sources of data, we hand coded the top 30 stories to ascertain which stories offered support for neutrality, which were in opposition, and which presented opinions from both sides of the debate. From the set of Media Cloud stories we generated link network maps by building a graph with media sources as nodes and links between media sources as unweighted edges. The graphs were laid out using the Graphviz neato algorithm. ${ }^{4}$ The images of the maps were generated with Gephi. ${ }^{5}$

\begin{tabular}{ll}
\hline Media Cloud & $\begin{array}{l}\text { Collection of 16k+ media stories and categorization by media type } \\
\text { Network mapping } \\
\text { Analysis of links between different media sources and stories }\end{array}$ \\
\hline Twitter & $\begin{array}{l}\text { Volume of tweets over time } \\
\text { Most frequently shared links }\end{array}$ \\
\hline Bit.ly & Stories that received the most clicks \\
\hline Google trends & Relative volume of net searches over time \\
\hline Content analysis & Hand coding of top stories, links shared on Twitter, and clicks via bit.ly \\
\hline
\end{tabular}

Table 1. Data Sources and Analytical Approaches

\section{Overview of the debate}

Tracking and tabulating the inlinks to different stories and media sources offers a measure of the prominence and popularity of different voices and viewpoints among the cohort of authors that write about the issue. The more than 10,000 inlinks from this network are distributed across 4,390 stories representing 925 media sources.

\footnotetext{
${ }^{4}$ http://www.graphviz.org/

${ }^{5}$ https://gephi.github.io/
} 


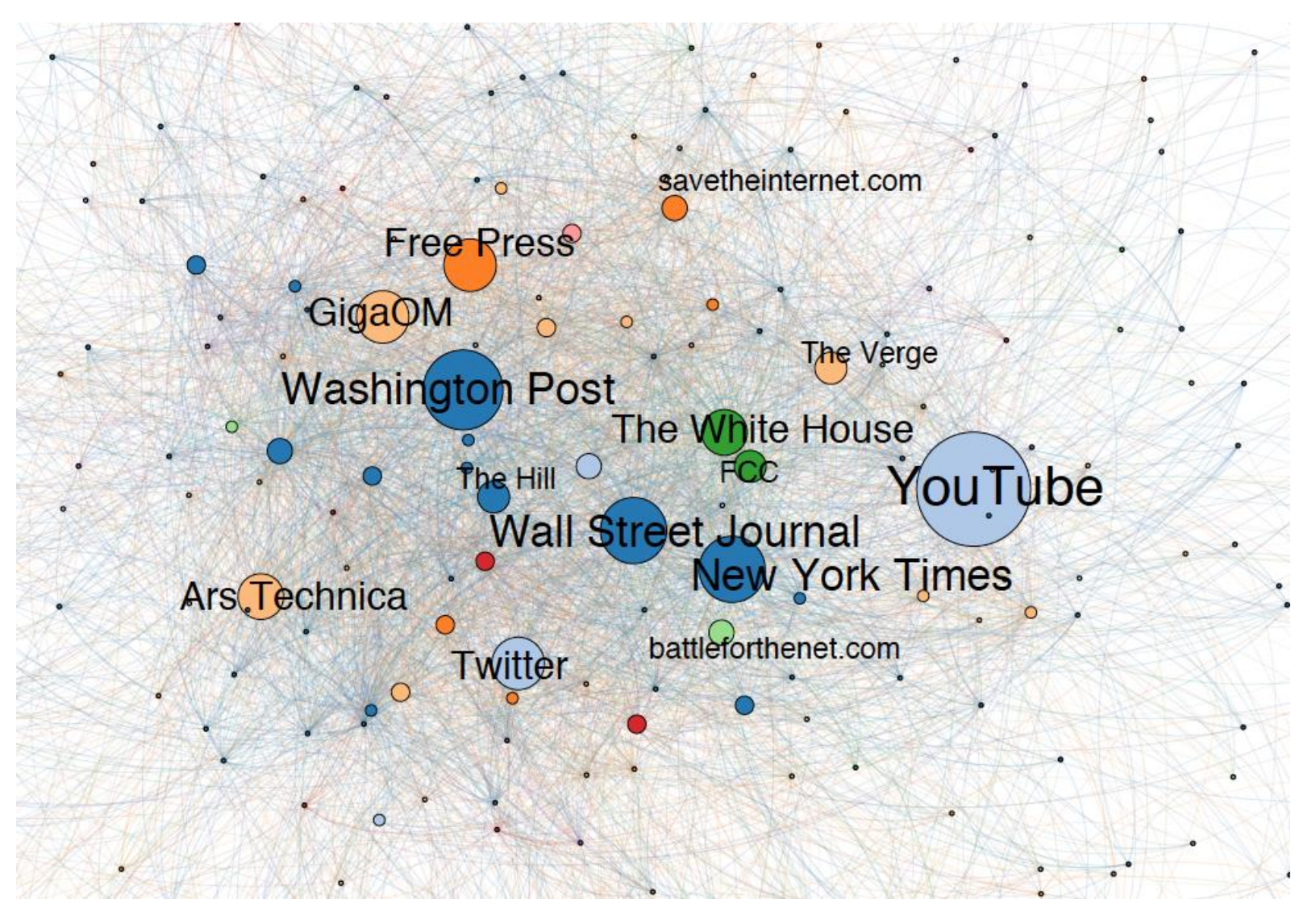

Figure 1. January 1 - November 17

As seen in Figure 1, a diverse set of media sources play prominent roles in the net neutrality debate in 2014. In this figure, the size of each node reflects the total number of inlinks to the media source and the colors denote different media types. YouTube, a user generated media site, is the source that received the most inlinks. These inlinks are distributed across more than 150 videos that received at least one inlink. John Oliver's June 1st video was the most popular with nearly 200 inlinks. Twitter appears among the top ten media sources with inlinks spread across many accounts.

After YouTube, three mainstream media sites received the most inlinks: the Washington Post, Wall Street Journal, and the New York Times (Table 2). Both the reputation of these publications and the large number of stories that each wrote on net neutrality contribute to their influential role. The prominence of these large media sources suggests that a good portion of the upper end of the power law distribution followed the traditional media playbook. Two government sources are in the top ten: the White House and the FCC. A number of tech media organizations were among the most linked-to sites, including GigaOm, Ars Technica, and the Verge. These and other tech media outlets covered the story in depth for the duration of the debate. 


\begin{tabular}{|lrrr|}
\hline Media Source & Inlinks & Outlinks & Stories \\
\hline YouTube & 547 & 4 & 173 \\
\hline Washington Post & 402 & 103 & 341 \\
\hline Wall Street Journal & 326 & 32 & 251 \\
\hline New York Times & 326 & 80 & 205 \\
\hline Free Press & 281 & 70 & 116 \\
\hline Twitter & 279 & 0 & 129 \\
\hline GigaOM & 266 & 264 & 294 \\
\hline The White House & 254 & 7 & 25 \\
\hline Ars Technica & 229 & 178 & 279 \\
\hline The Hill & 184 & 21 & 155 \\
\hline FCC & 178 & 0 & 10 \\
\hline The Verge & 171 & 89 & 135 \\
\hline battleforthenet.com & 156 & 4 & 3 \\
\hline Wikipedia & 152 & 0 & 27 \\
\hline Hufffington Post & 141 & 317 & 270 \\
\hline savetheinternet.com & 128 & 35 & 31 \\
\hline Netflix & 123 & 0 & 2 \\
\hline Yahoo! & 119 & 80 & 408 \\
\hline Wired & 117 & 87 & 95 \\
\hline EFF & 111 & 43 & 38 \\
\hline CNET & 108 & 80 & 131 \\
\hline Guardian & 103 & 48 & 86 \\
\hline Comcast & 98 & 1 & 22 \\
\hline Public Knowledge & 97 & 16 & 52 \\
\hline National Journal & 96 & 22 & 52 \\
\hline
\end{tabular}

Table 2. Inlinks, outlinks, and stories by media source

Advocacy organizations not only provided coverage of the events in a fashion similar to traditional media but also helped to mobilize public support for net neutrality. Free Press, the Electronic Frontier Foundation (EFF), Public Knowledge, and net neutrality campaign sites — most notably BattlefortheNetare consistently among the most linked-to sites throughout the controversy. Public statements by corporate actors were also featured in the debate: Netflix came out as a strong voice in favor of net neutrality, while Comcast, AT\&T, and Verizon offered strong opposition, although among the corporate opposition, only Comcast appears in the top 25 media sources. As we present in detail later, the attention paid to the major broadband providers was primarily through links from stories that are either critical or neutral of those companies, not from supporters. 


\section{The 2014 Net Neutrality Debate in Nine Acts}

We describe the arc of digital media coverage of the net neutrality debate surrounding nine key events. Six of these nine events are driven by government action: a court decision in January, FCC policy proceedings, and a major policy statement by the president. Both mainstream and non-traditional media play important roles in the coverage of these events. The remaining three events were not tied to government action. The uptick in March was in response to a blog post by the CEO of Netflix. The spike in traffic in the first week of June was instigated by John Oliver. The upsurge in September was precipitated by the social mobilization efforts of Internet activists.

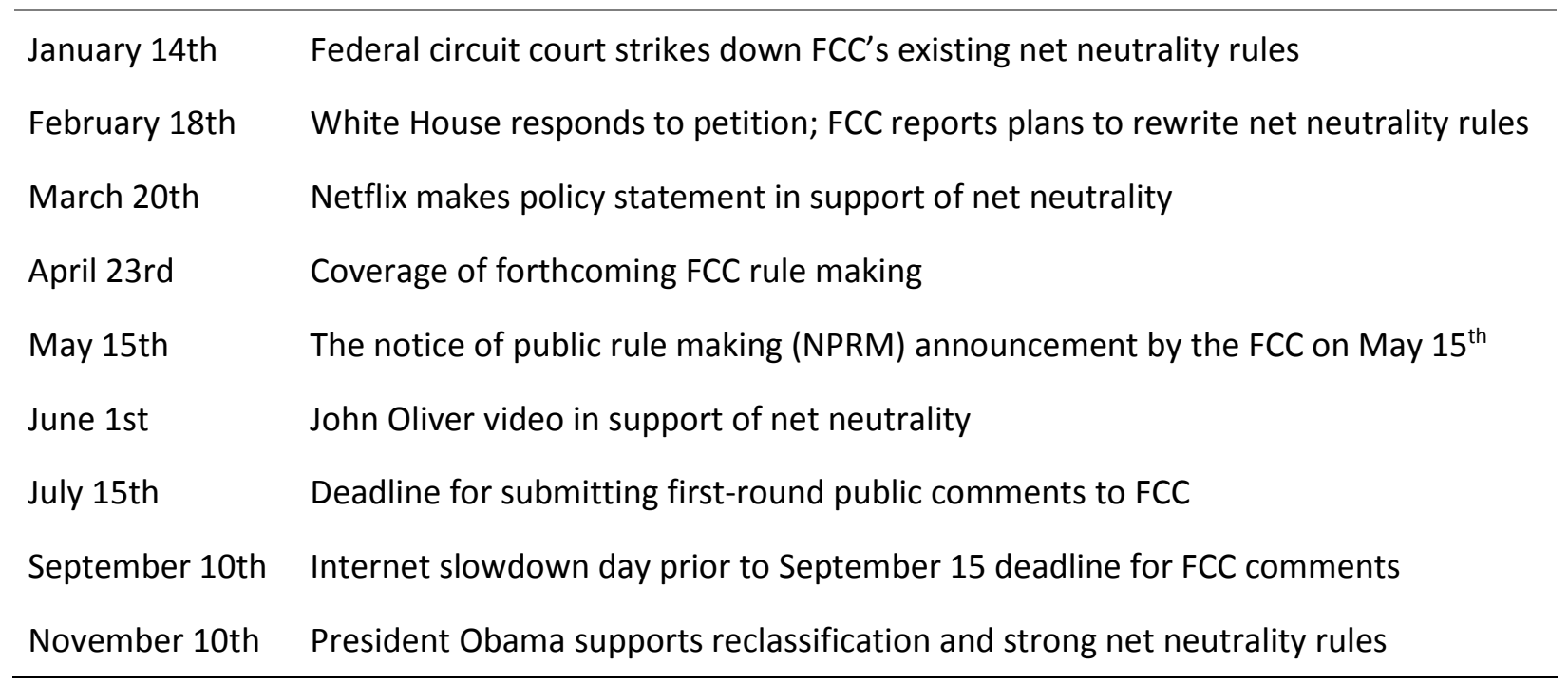

Table 3. Key Milestones in the Net Neutrality Debate in 2014

As seen in Figure 2, the relative distribution of stories in digital media and Twitter activity related to net neutrality are closely aligned over time. Obama's November 10th pubic statement in support of strong net neutrality garnered the most attention, followed by the FCC's May 15th release of draft net neutrality rules. 


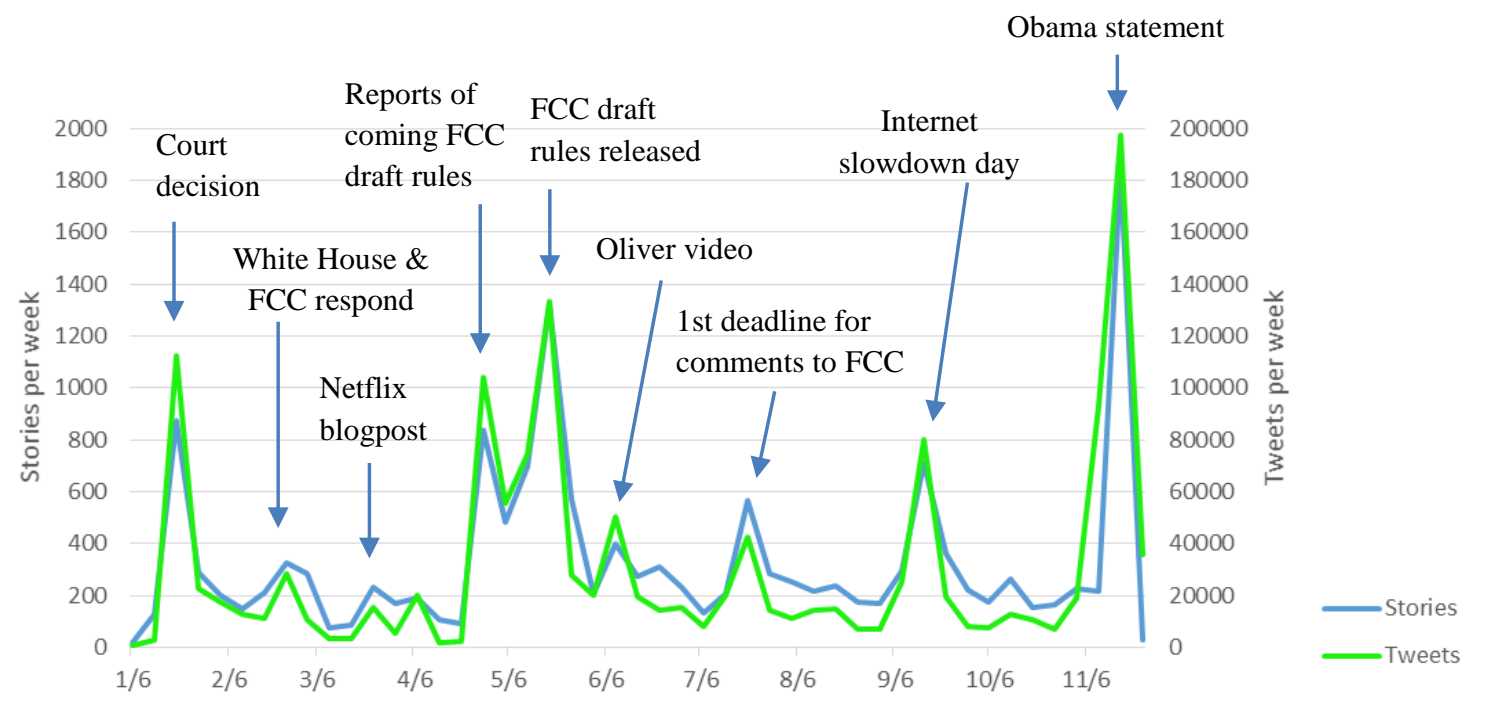

Figure 2. Volume of stories and tweets over time

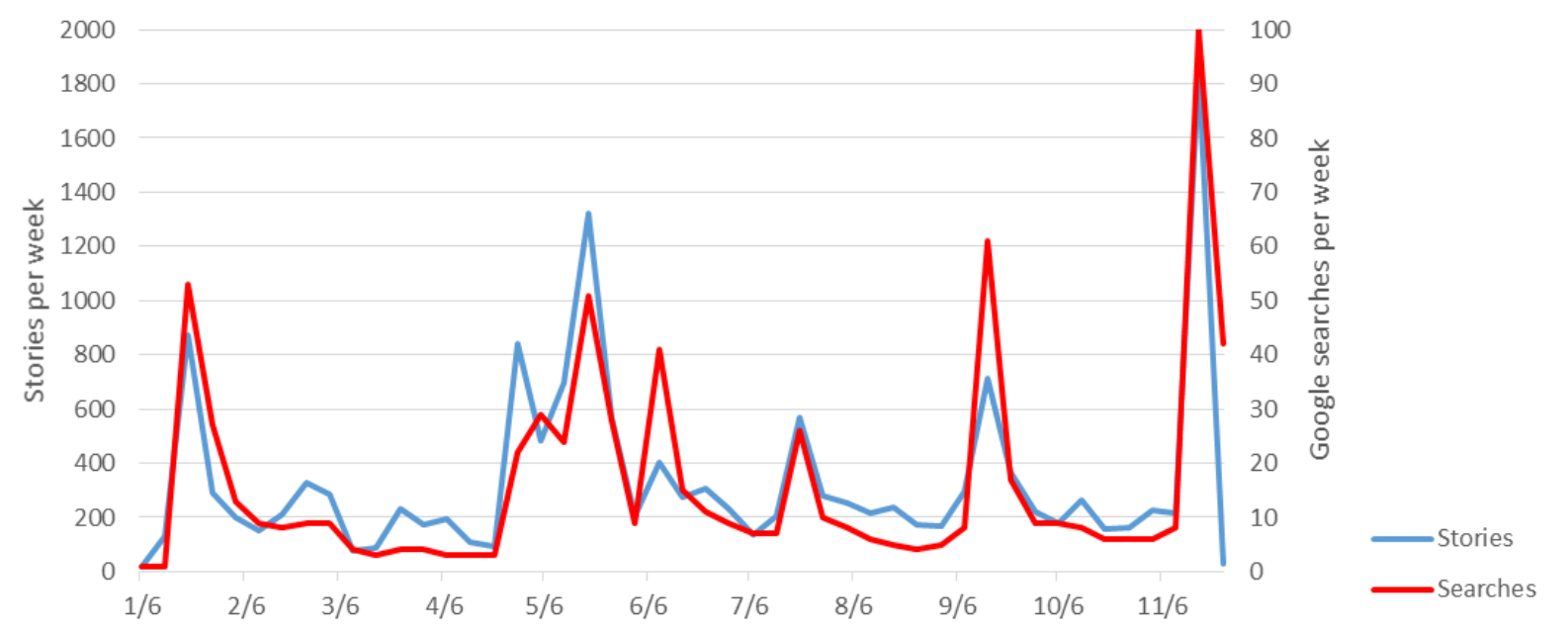

Figure 3. Volume of stories and Google searchers over time

The relative volume of Google searches over time also follows the profile of digital media stories with a few notable differences (Figure 3). The reporting of events in February and March did not prompt a commensurate rise in Google searches. In April, while Google searches rose sharply with the news of a forthcoming FCC ruling, the searches did not keep pace with the media coverage. The other two outliers are the disproportionate volume of searches in June (coinciding with the John Oliver show on net neutrality) and the Internet slowdown day in September. This suggests that these are media events of a different form compared to the other events driven by government action. 


\section{Act 1 - D.C. Circuit Court strikes down FCC net neutrality rules}

The first burst of activity occurs on January 14th 2014 when the D.C. Circuit Court issues a ruling that struck down the FCC's 2010 Open Internet Order that embodied the net neutrality guidelines in place up to that point. ${ }^{6}$ This court decision came in response to Verizon's challenge to the 2010 FCC order. The court struck down the portions of the guidelines that prevented broadband providers from the creation of "fast lanes" and prohibited selected blocking of traffic. The court based its decision not on the substance of the rules, but on jurisdictional grounds. The Commission could not impose nondiscrimination provisions that effectively required these providers to act as common carriers as long as the FCC continued to define broadband services as "information services" rather than as "telecommunications services.”

The January court decision shifted responsibility back to the FCC to reconsider whether and how to reintroduce net neutrality rules. The FCC had two principal options to consider. One would continue to use the same jurisdictional designation to which the FCC had shifted in the early 2000s, and redraft net neutrality rules within this institutionally constrained framework under Section 706 of the Telecommunications Act. The court ruling had affirmed that the FCC had the statutory authority to use Section 706 to regulate Internet traffic but that the prior rules went too far towards regulating broadband providers as common carriers. While some lauded the decision as a blow against net neutrality, others read the court's ruling, which affirmed the FCC's authority to regulate Internet traffic under Section 706, as a defeat for those opposed to regulatory action. ${ }^{7}$ The second, more assertive option for the FCC would be to reclassify broadband providers as common carriers subject to regulation under Title II of the Telecommunications Act. This would reverse a series of decisions the FCC had taken between 2001 and 2005 that classified broadband as an "information service," decisions later upheld as permissible, though not required, by the Supreme Court in Brand X. ${ }^{8}$ These classification decisions placed broadband services in a loosely defined "ancillary jurisdiction" bucket, under Title I of the Telcommunications Act. The ambiguity of the FCC's authority under that title has been at the heart of court battles over net neutrality ever since. The more ambitious option, from the perspective of net neutrality supporters, would be to go

\footnotetext{
${ }^{6}$ https://apps.fcc.gov/edocs_public/attachmatch/FCC-10-201A1.pdf

${ }^{7}$ https://cei.org/news-releases/net-neutrality-court-ruling-praised-cei-experts http://techfreedom.org/post/73327053584/court-strikes-down-net-neutrality-rules-but-grants http://www.theatlantic.com/technology/archive/2014/01/the-courts-net-neutrality-ruling-isnt-actually-that$\mathrm{bad} / 283094 /$ http://volokh.com/2014/01/14/winning-losing-net-neutrality-decision/

${ }^{8}$ NCTA v. Brand X, 545 U.S. 967 (2005).
} 
after the root weakness of the FCC's net neutrality efforts over the past decade and reclassify broadband back to its designation before 2001, as a telecommunications service subject to Title II of the Telecommunications Act, which offers the FCC much more robust authority. Legally, the latter option is cleaner, since Title II has a long history and a clear statutory framework, while the use of Title I regulation has been rare and only temporary. Politically, however, reclassification was by far the heavier lift, precisely because it would put regulation on a much clearer legal foundation.

Because the FCC had these two options open to it, observers from both sides of the debate noted that the D.C. Circuit decision was not a clear victory for either side; the outcome would depend in part on the FCC's next move, and the inevitable court challenges that would follow. A great fear among those opposed to government regulation of Internet access and hope for those in favor of government intervention was that the FCC would now be forced to reclassify broadband as a telecommunications service. The January court decision so constrained the range of net neutrality rules the FCC could pass that it might have provided just enough impetus for the FCC to seek to solidify its regulatory power and ultimately issue stronger net neutrality rules. Marvin Ammori aptly framed this possibility in a piece in Slate titled: "The Net Neutrality Fight has been Lost; Now We Can Finally Win the War."9

\begin{tabular}{|l|l|r|}
\hline Story & Media Source & Inlinks \\
\hline Ensuring an Open Internet Now and for the Future & FCC & 18 \\
\hline DC Net Neutrality ruling & scribd.com & 18 \\
\hline VC Pitches In A Year Or Two & A VC & 18 \\
\hline Appeals Court Strikes Down FCC's Net Neutrality Rules & Wall Street Journal & 17 \\
\hline Court strikes down FCC's net neutrality rules & GigaOM & 17 \\
\hline
\end{tabular}

Table 4. Stories with most inlinks, week of January 13 - 20

We identified almost 900 stories that covered net neutrality during the week of January 14th. The most linked-to stories came from a broad range of media sources, including FCC Chairman Tom Wheeler's response, a blog post by venture capitalist Fred Wilson, the text of the court decision, and coverage by traditional and tech media outlets (Table 4).

9

http://www.slate.com/articles/technology/future_tense/2014/01/net_neutrality_d_c_circuit_court_ruling_the_ba ttle_s_been_lost_but_we_can.html 


\section{Act 2 - Responses from the White House and FCC; Netflix and Verizon scuffle}

There was a modest increase in media coverage in the middle of February when the White House responded to a petition on the We the People website that asked the President to direct the FCC to reclassify Internet service providers as common carriers (Table 5). This petition received over 100,000 signatures. The response from the White House deferred to the FCC: "The FCC is an independent agency. Chairman Wheeler has publicly pledged to use the full authority granted by Congress to maintain a robust, free and open Internet -- a principle that this White House vigorously supports." ${ }^{10}$ The FCC also announced the same week that it would issue new net neutrality rules later in the spring. Another issue that received attention at this time was the ongoing conflict between Netflix and Verizon, which had been fueled by the release of data by Netflix showing that the delivery of its videos were slowing over time. ${ }^{11}$

\begin{tabular}{|l|l|r|}
\hline Story & Media Source & Inlinks \\
\hline $\begin{array}{l}\text { Restore Net Neutrality By Directing the FCC to Classify Internet } \\
\text { Providers as Common Carriers }\end{array}$ & $\begin{array}{l}\text { The White House } \\
\text { petition }\end{array}$ & 10 \\
\hline Reaffirming the White House's Commitment to Net Neutrality & $\begin{array}{l}\text { The White House } \\
\text { petition response }\end{array}$ & 9 \\
\hline FCC Plans to Issue New Net Neutrality Rules & Wall Street Journal & 6 \\
\hline $\begin{array}{l}\text { Verizon using recent Net Neutrality victory to wage war against } \\
\text { Netflix }\end{array}$ & davesblog.com \\
\hline $\begin{array}{l}\text { Netflix performance on Verizon and Comcast has been dropping for } \\
\text { months }\end{array}$ & Ars Technica & 4 \\
\hline
\end{tabular}

Table 5. Stories with most inlinks, week of February 17 - 24

\section{Act 3 - Netflix takes center stage}

Coverage of net neutrality quieted down for the next several weeks while waiting for the next move by the FCC. An uptick in activity occurred in the middle of March (Table 6), instigated by a blog post by the CEO of Netflix, Reed Hastings ("Internet Tolls and the Case for Strong Net Neutrality") and a response from AT\&T ("Who Should Pay for Netflix"). While small compared to the later stages of the debate, this exchange came at a time when there was relatively little media coverage of net neutrality. The Netflix statement would become a point of reference for subsequent coverage and discussion. This blogpost is the third most-linked-to story overall in the controversy, behind only the John Oliver video to come in June

\footnotetext{
${ }^{10}$ http://www.whitehouse.gov/blog/2014/02/17/we-people-response-reaffirming-white-houses-commitment-netneutrality

${ }^{11}$ http://www.theverge.com/2014/6/5/5783338/verizon-sends-netflix-cease-and-desist-over-congestion-warnings
} 
and President Obama's November statement. Although both the Washington Post and the New York Times reported on the Netflix post, offering views from both sides of the debate, a large majority of the links and attention went to the original Netflix blog post.

\begin{tabular}{|l|l|r|}
\hline Story & Media Source & Inlinks \\
\hline Internet Tolls and the Case for Strong Net Neutrality & Netflix Blog & 12 \\
\hline Who Should Pay for Netflix? & $\begin{array}{l}\text { AT\&T Public Policy } \\
\text { Blog }\end{array}$ & 5 \\
\hline $\begin{array}{l}\text { Netflix \& Level 3 Only Telling Half The Story, Won't Detail What } \\
\text { Changes They Want to Net Neutrality }\end{array}$ & streamingmedia.com \\
\hline $\begin{array}{l}\text { "Chicken" | A Game Played as a Child and by some ISPS with the } \\
\text { Internet }\end{array}$ & $\begin{array}{l}\text { Level 3 } \\
\text { Communications Blog }\end{array}$ & 4 \\
\hline Hey FCC, Netflix thinks peering should be a net neutrality issue too & GigaOM & 4 \\
\hline
\end{tabular}

Table 6. Stories with most inlinks, week of March $17-24$

\section{Act 4 - News of forthcoming draft net neutrality rules}

The next spike in activity started when the Wall Street Journal reported on April 23rd that the FCC planned to propose new net neutrality rules that would allow broadband providers and content providers to negotiate deals to prioritize traffic (Table 7). This news was met with a barrage of condemnations coming from net neutrality advocates. The title of Tim Wu's article in the New Yorker conveyed the sentiment well: "Goodbye Net Neutrality; Hello Net Discrimination". ${ }^{12}$ Over 800 stories comprised the coverage during this week. While stories by the Wall Street Journal, New York Times, and Washington Post received the most inlinks, a range of other prominent sources included tech media, government, companies, and advocacy organizations shared attention. This is the only phase of the debate in which mainstream media sources occupied the top several positions in the link economy.

\footnotetext{
12 http://www.newyorker.com/tech/elements/goodbye-net-neutrality-hello-netdiscrimination?utm_source=nextdraft\&utm_medium=email
} 


\begin{tabular}{|l|l|r|}
\hline Story & \multicolumn{1}{l|}{ Media Source } & 80 \\
\hline FCC to Propose New Net Neutrality Rules & Wall Street Journal & 47 \\
\hline F.C.C., in a Shift, Backs Fast Lanes for Web Traffic & New York Times & 23 \\
\hline Goodbye, Net Neutrality; Hello, Net Discrimination & The New Yorker & 19 \\
\hline $\begin{array}{l}\text { The FCC is planning new net neutrality rules and they could enshrine } \\
\text { pay for play }\end{array}$ & Washington Post & 16 \\
\hline Internet Tolls and the Case for Strong Net Neutrality & Netflix Blog & \\
\hline
\end{tabular}

Table 7. Stories with most inlinks, week of April $21-28$

The compromise solution devised by Wheeler appeared to satisfy few. Coverage of the story over the following two weeks remained high as advocacy efforts kicked into gear. Internet activists, politicians, and companies issued statements, some urging the FCC to adopt stricter net neutrality rules and others to abandon them altogether. A number of tech companies, including Amazon, Facebook, Google, Microsoft, Netflix, Twitter, and Yahoo! wrote a letter on May 7th to the FCC commissions indicating that rules permitting paid prioritization would represent "a grave threat to the internet."13

\section{Act 5 - New draft net neutrality rules are released}

On May 15th, the FCC voted in favor of a preliminary proposal that appeared to open the door to paid prioritization of traffic if shown to be "commercially reasonable"-Wheeler contested this interpretation, saying "I've consistently said, there is only one Internet. There is not a fast or slow Internet." ${ }^{14} \mathrm{His}$ assertions were met with skepticism by many. ${ }^{15}$ The attacks came from both sides. The issue of the draft proposal, a Notice of Proposed Rule Making (NPRM), marked the opening of a period for the public to

\footnotetext{
${ }^{13}$ http://cdn1.vox-cdn.com/assets/4422119/letter_to_FCC.pdf

${ }^{14} \mathrm{http}: / /$ www.politico.com/story/2014/05/tom-wheeler-fcc-net-neutrality-defend-106894.html

${ }^{15} \mathrm{http}: / /$ arstechnica.com/tech-policy/2014/05/fcc-votes-for-internet-fast-lanes-but-could-change-its-mind-later/ https://gigaom.com/2014/05/15/net-neutrality-

2014/?utm_source=feedburner\&utm_medium=feed\&utm_campaign=Feed\%3A+OmMalik+\%28Gigaom+News+\%2 6+Research\%29

http://www.washingtonpost.com/blogs/the-switch/wp/2014/05/15/fcc-approves-plan-to-allow-for-paid-priorityon-internet/
} 
comment on the proposal. The first commenting period extended to July 15 th, and a second period to allow public responses to comments ran into September.

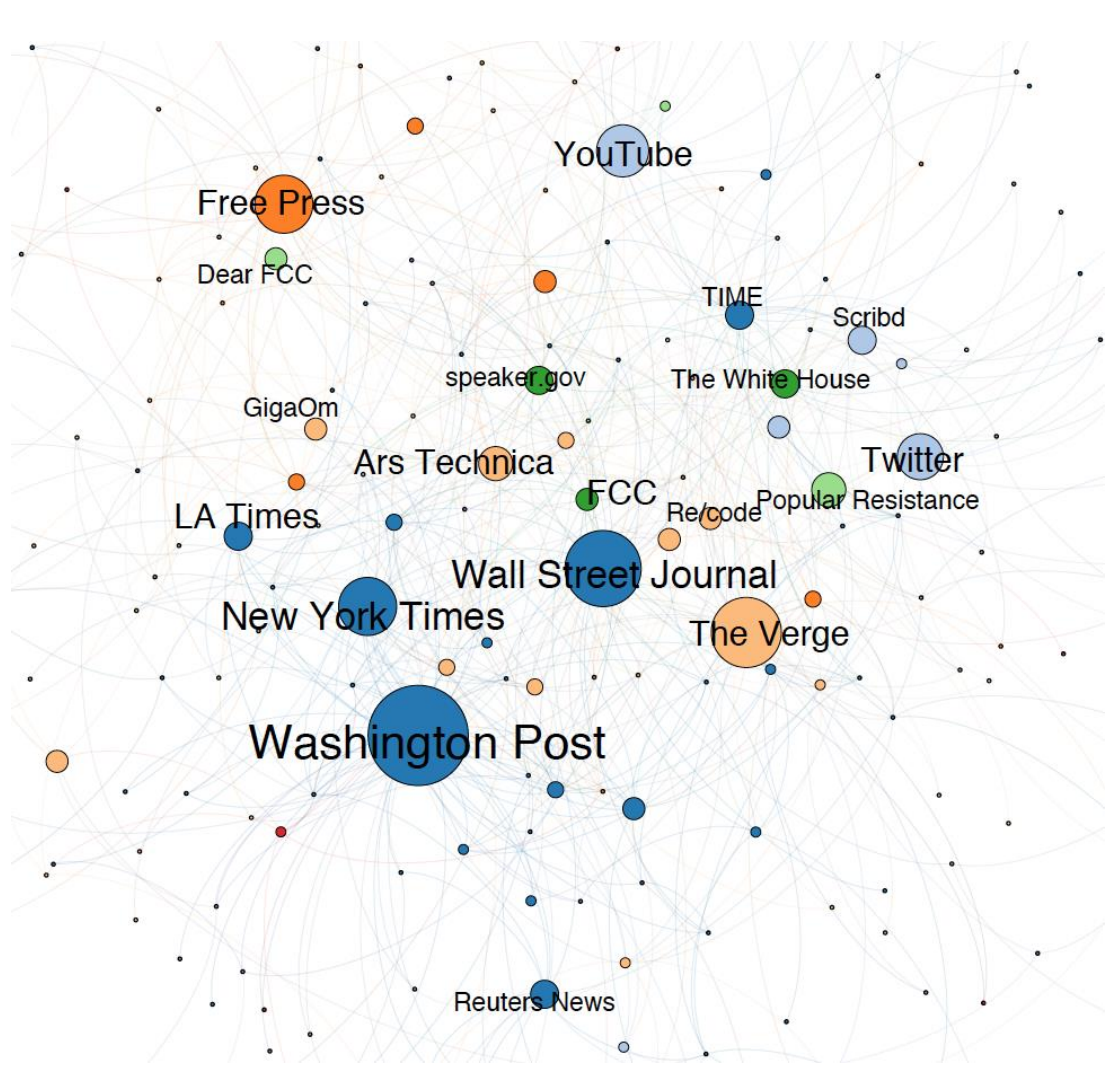

Figure 4. May $12-19$

\begin{tabular}{|l|l|r|}
\hline Story & \multicolumn{1}{l|}{ Media Source } \\
\hline FCC to Propose New Net Neutrality Rules & Wall Street Journal & 15 \\
\hline Dear Chairman Wheeler: & speaker.gov & 15 \\
\hline Maintain True Net Neutrality & White House petition & 15 \\
\hline Dear FCC, & dearfcc.org & 12 \\
\hline $\begin{array}{l}\text { Here's that FCC net neutrality compromise everyone demanded. } \\
\text { And here's the problem. }\end{array}$ & GigaOM & 12 \\
\hline
\end{tabular}

Table 8. Stories with most inlinks, week of May $12-19$

The week of the May $15^{\text {th }}$ announcement saw another surge of media coverage with more than 1,300 stories. A broad range of sources received inlinks, although in a relatively flat distribution of inlinks (Table 
8). Topping the list are a White House petition urging strong net neutrality, a letter from Speaker Boehner and colleagues coming out against net neutrality, a Wall Street Journal article, and DearFCC.org, an advocacy site put up by EFF to promote and facilitate public submissions to the FCC in support of net neutrality.

\section{Act 6 - John Oliver delivers long-form rant about net neutrality}

Advocacy efforts in support of net neutrality ramped up through May and June with protests at the FCC and coordinated efforts to call and write to the FCC. There was another rise in coverage in the first week of June (just over 400 stories) driven in large part by links to a YouTube video of John Oliver's show in which he aims his caustic wit at the FCC and net neutrality opponents (Table 9). This video would become a prominent touch point for net neutrality advocates and the most popular link in the course of the controversy. The YouTube video had been viewed over 7 million times by January 2015 with the 'likes' outnumbering the 'dislikes' at a rate of 100:1.

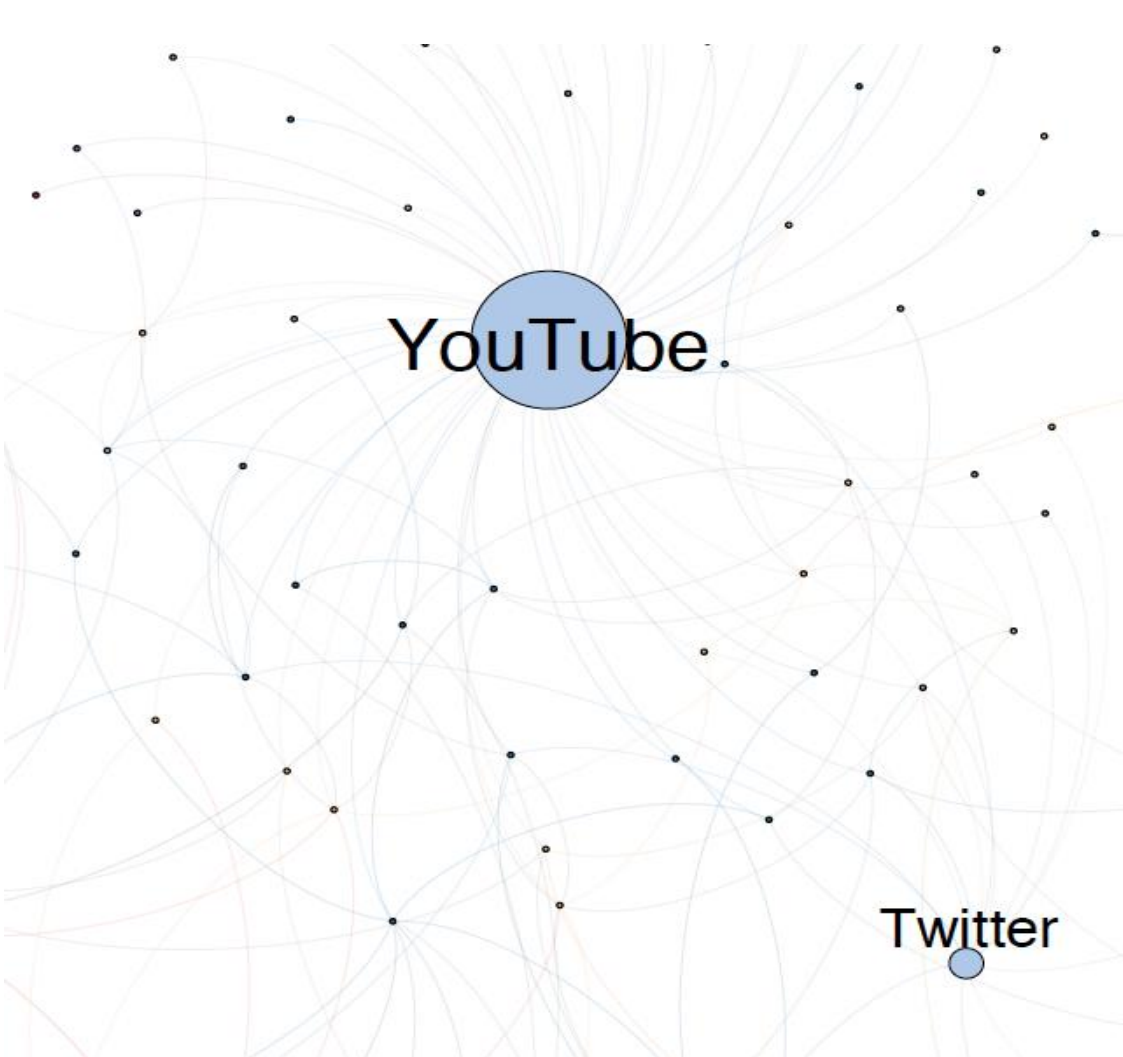

Figure 5. June 2- 9 


\begin{tabular}{|l|l|r|}
\hline Story & \multicolumn{1}{c|}{ Media } \\
\hline & \multicolumn{1}{c|}{ Source } \\
\hline Last Week Tonight with John Oliver: Net Neutrality & YouTube & 72 \\
\hline Internet Tolls and the Case for Strong Net Neutrality & Netflix & 11 \\
\hline Dear FCC, & dearfcc.org & 6 \\
\hline $\begin{array}{l}\text { Cable Companies Are Astroturfing Fake Consumer Support to End Net } \\
\text { Neutrality }\end{array}$ & vice.com & 5 \\
\hline $\begin{array}{l}\text { Twitter / FCC: We've been experiencing technical difficulties with our } \\
\text { comment system due to high traffic. }\end{array}$ & Twitter & 5 \\
\hline
\end{tabular}

Table 9. Stories with most inlinks, week of June 2 - 9

There was a surge in comments submitted to the FCC fed by the Oliver video. Well into the commenting period, the FCC reported that its website had problems handling the high volume of submissions.

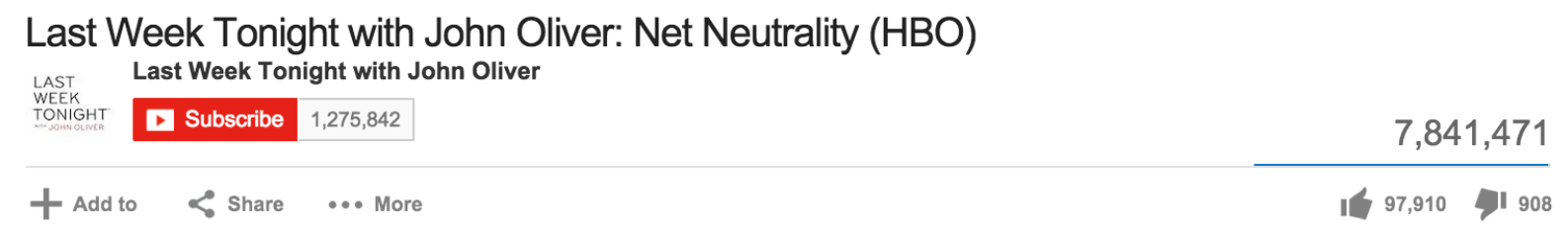

Image 1. John Oliver's clip on Net Neutrality uploaded June $1^{\text {st }}, 2014$

ほ

The FCC

QFCC

to Follow

We've been experiencing technical difficulties

with our comment system due to heavy

traffic. We're working to resolve these issues

quickly.

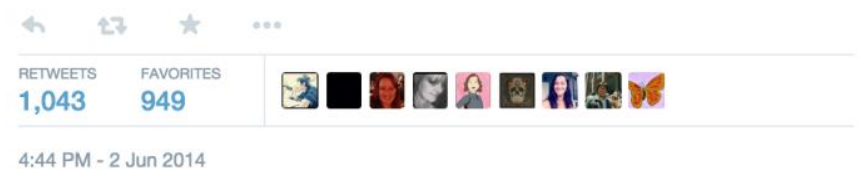

Image 2. Tweet from the FCC's official Twitter account, June $2^{\text {nd }}, 2014$

Netflix continued to play a provocative role in the debate and contribute to the media agenda: this time by sending its users an error message that attributed problems with video streaming to Verizon: "The 
Verizon network is crowded right now." ${ }^{16}$ An article by Vice in this week presented evidence that industry groups were funding advocacy groups to oppose net neutrality, "astroturfing fake consumer support." 17

\section{Act 7 - Advocacy efforts ramp up; closing of first public commenting period}

Coverage rose again the week of July 14th to almost 600 stories, bolstered by the end of the first round of comments to the FCC, while Oliver's video continued to attract many links (Table 10). A number of organizations that support net neutrality, including EFF, Free Press, Demand Progress, Engine, the Nation, and CredoAction, offered online forms to make it easy for people to submit comments to the FCC. BattlefortheNet, which would rise in prominence over the next several months, makes its first appearance in the link economy with the backing of "Team Internet." The most popular of the campaign sites opposed to net neutrality, DontBreaktheNet, would not launch until September. ${ }^{18}$

\begin{tabular}{|l|l|r|}
\hline Story & Media Source & Inlinks \\
\hline Last Week Tonight with John Oliver: Net Neutrality & YouTube & 20 \\
\hline $\begin{array}{l}\text { This is why your Internet is slow. And it'll get worse. Unless you } \\
\text { take } 1 \text { min to do this, now. }\end{array}$ & battleforthenet.com \\
\hline $\begin{array}{l}\text { Keeping Track of the Open Internet Comments Submitted to } \\
\text { the FCC }\end{array}$ & FCC & 6 \\
\hline Net Neutrality and Modern Memory & AT\&T Public Policy blog & 5 \\
\hline
\end{tabular}

Table 10. Stories with most inlinks, week of July $14-21$

While John Oliver's call for the Internet "monsters" to write to the FCC received much media attention and was undoubtedly responsible for a significant increase in activity in June, the response in mid-July was several times higher, suggesting that the organized efforts by advocacy organizations to elicit comments was more successful. ${ }^{19}$ The looming deadline and procrastination may have also shaped the

\footnotetext{
${ }^{16} \mathrm{http}: / / q z . c o m / 216609 /$ netflixs-video-error-message-is-a-clever-attack-on-cable-companies/

${ }^{17} \mathrm{http} / / /$ www.vice.com/read/cables-companies-are-astroturfing-fake-consumer-support-to-end-net-neutrality

${ }^{18} \mathrm{http}: / /$ dontbreakthe.net/

${ }^{19} \mathrm{http}$ ://www.fcc.gov/blog/update-volume-open-internet-comments-submitted-fcc
} 
timing of comments. ${ }^{20}$ Analysis by the Sunlight Foundation found that comments linked to five advocacy efforts (CredoAction, BattlefortheNet, EFF, Daily Kos, and Avaaz), accounted for close to half of the 800,000 comments received in the first submission window. ${ }^{21}$

\section{Act 8 - Internet Slowdown Day}

Advocacy efforts coalesced around September 10th protests dubbed the "Internet slowdown." Protest organizers recruited websites to display the "spinning wheel of death" on their sites to remind users of the frustration of waiting for websites to load. Participating websites also urged visitors to contact law makers and demand action on net neutrality. The organizers reported that over 40,000 websites participated in the online protests.

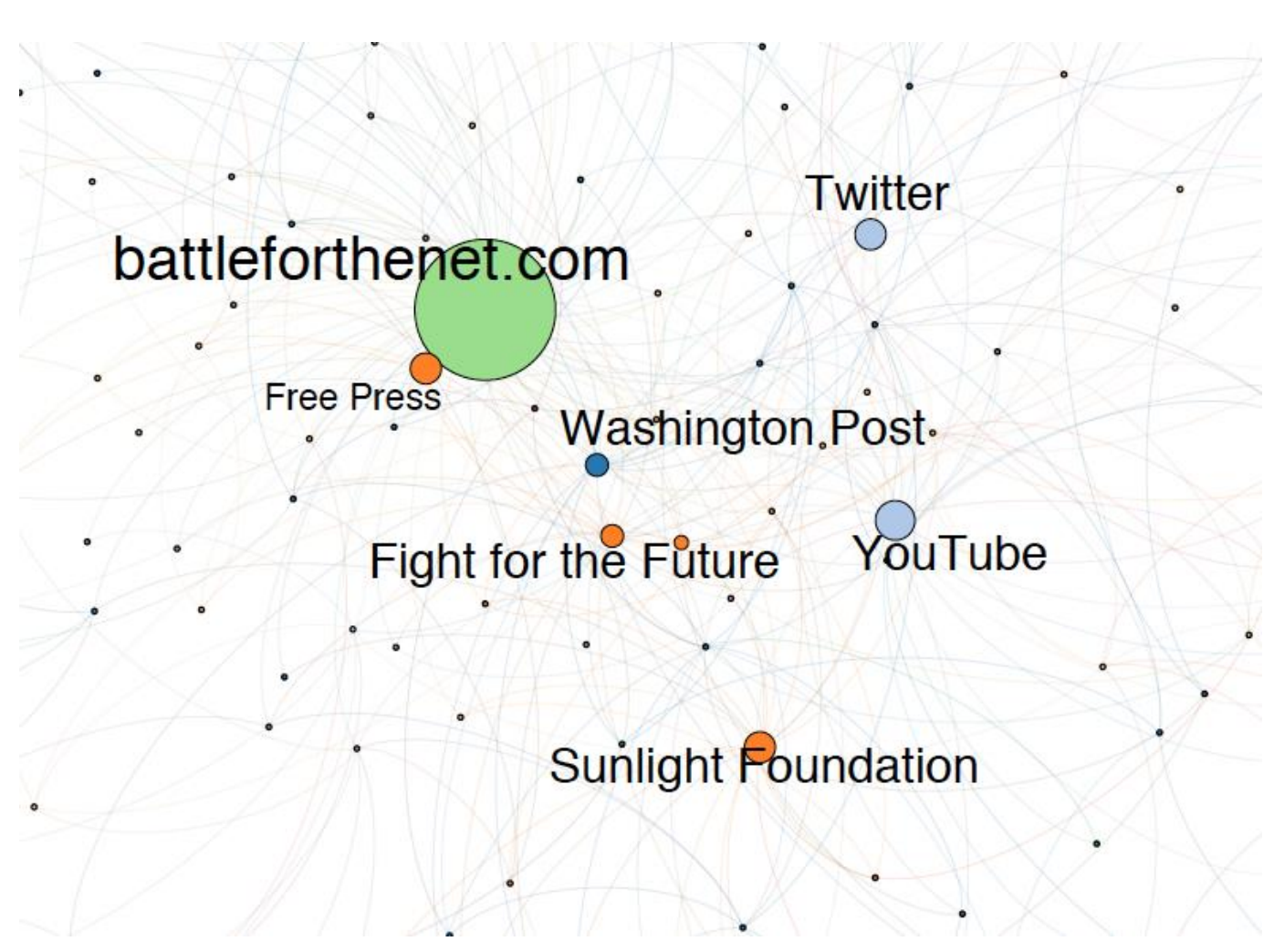

Figure 6. September $8-15$

\footnotetext{
${ }^{20} \mathrm{http} / / /$ www.washingtonpost.com/blogs/the-switch/wp/2014/09/18/on-net-neutrality-procrastination-is-aneven-more-powerful-force-than-john-oliver/

${ }^{21} \mathrm{http}: / /$ sunlightfoundation.com/blog/2014/09/02/what-can-we-learn-from-800000-public-comments-on-thefccs-net-neutrality-plan/
} 
In addition to drawing wide media coverage - coverage exceeded 700 stories that week - the Internet slowdown protest activities appear to have inspired a large number of people to contact the FCC, Congress, and the White House. The organizers behind the site BattlefortheNet alone counted up over two million emails sent, more than three hundred thousand phone calls, and close to eight hundred thousand additional comments to the FCC. ${ }^{22}$ Advocates backing net neutrality had made an unmistakably strong statement with a vanishingly small response from the other side.

\begin{tabular}{|l|l|r|}
\hline Story & \multicolumn{1}{r|}{ Media Source } & 66 \\
\hline Battle For The Net & battleforthenet.com & 37 \\
\hline $\begin{array}{l}\text { This is why your Internet is slow. And it'll get worse. Unless you } \\
\text { take } 1 \text { min to do this, now. }\end{array}$ & battleforthenet.com & 21 \\
\hline Last Week Tonight with John Oliver: Net Neutrality & YouTube & 20 \\
\hline $\begin{array}{l}\text { What can we learn from 800,000 public comments on the FCC's } \\
\text { net neutrality plan? }\end{array}$ & sunlightfoundation.com & 12 \\
\hline Save the Internet: Net Neutrality & savetheinternet.com & \\
\hline
\end{tabular}

Table 11. Stories with most inlinks, week of September 8 - 15

Unlike the prior round, the second round of the commenting period included a large number of responses opposing net neutrality. The Sunlight Foundation again analyzed the results and reported: ${ }^{23}$

In marked contrast to the first round, anti-net neutrality commenters mobilized in force for this round, and comprised the majority of overall comments submitted, at $60 \%$. We attribute this shift almost entirely to the form-letter initiatives of a single organization, American Commitment, who are single-handedly responsible for $56.5 \%$ of the comments in this round.

They also reported that the sentiment among the non-form letters was similar to that of the first round with only about $1 \%$ of responses opposing net neutrality. It is difficult to draw firm conclusions from the second round of comments for a couple of reasons. First, there is a large discrepancy between the data

\footnotetext{
${ }^{22} \mathrm{https}: / /$ www.battleforthenet.com/sept10th/

${ }^{23} \mathrm{http}: / /$ sunlightfoundation.com/blog/2014/12/16/one-group-dominates-the-second-round-of-net-neutralitycomments/
} 
that Sunlight received from the FCC and the number of submissions that the FCC had reported. ${ }^{24}$ Fight for the Future claims that the FCC data acquired by Sunlight significantly undercounts pro-net neutrality comments. ${ }^{25}$ Second, it is difficult to draw inferences from the responses of the two campaigns which used such different techniques. The American Commitment campaign was almost completely absent from the link economy but instead reportedly relied upon paid email distributions to attract commenters. ${ }^{26}$

\section{Act 9 - Obama backs strong net neutrality and Title II reclassification}

On November 10th, President Obama spoke out in favor of strong net neutrality rules and Title II reclassification of broadband, bringing about the largest surge in media attention during the year. Over 1,850 stories on net neutrality appeared in this week, with a large proportion of the inlinks going to the official White House statement (Table 12). After the White House announcement page (150 inlinks), Ted Cruz' response via Twitter received the second most attention with 29 inlinks. Responses from Verizon and Comcast were also in the top five, with 24 and 19 inlinks respectively.

\begin{tabular}{|l|l|r|}
\hline Story & \multicolumn{1}{l|}{ Media Source } & Inlinks \\
\hline Net Neutrality: President Obama's Plan for a Free and Open Internet & The White House & 143 \\
\hline $\begin{array}{l}\text { Net Neutrality is Obamacare for the Internet; the Internet should not } \\
\text { operate at the speed of government. (Sen. Ted Cruz) }\end{array}$ & Twitter & 29 \\
\hline Verizon Statement on White House Title II Announcement & Verizon Policy Blog & 24 \\
\hline Last Week Tonight with John Oliver: Net Neutrality & YouTube & 19 \\
\hline Surprise! We Agree with the President's Principles on Net Neutrality & Comcast Voices & 19 \\
\hline
\end{tabular}

Table 12. Stories with most inlinks, week of November 10 - 17

\footnotetext{
${ }^{24}$ http://sunlightfoundation.com/blog/2014/12/17/clearing-up-the-confusion-about-our-analysis-of-netneutrality-comments-to-the-fcc/

${ }^{25}$ http://tumblr.fightforthefuture.org/post/105452007918/fcc-and-sunlight-foundation-drastically

${ }^{26}$ http://motherboard.vice.com/en_ca/read/the-conservative-anti-net-neutrality-movement-that-wasnt
} 


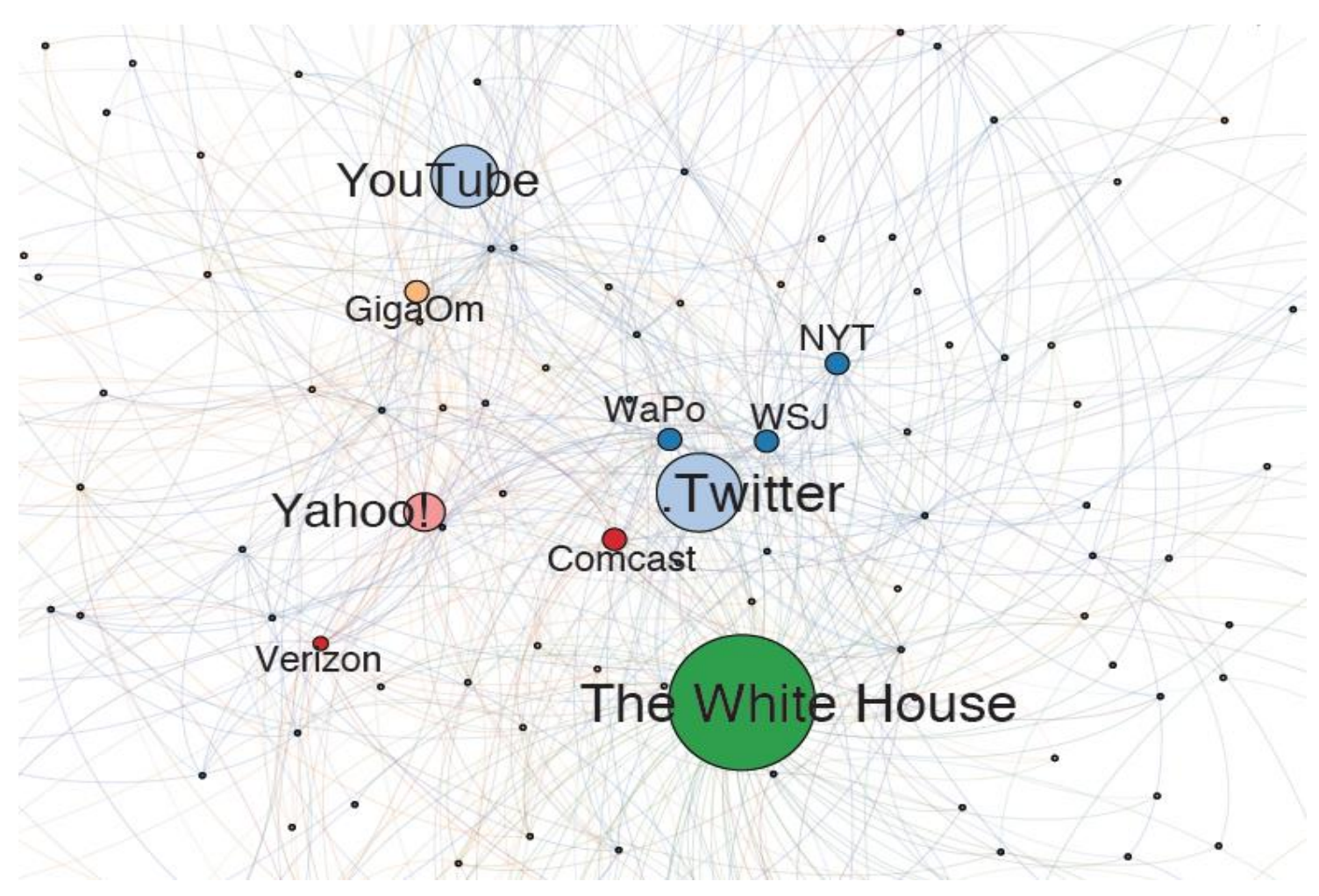

Figure 7. November 10 - 17

\section{The Link Economy Backs Net Neutrality}

Among the more than 16,000 stories that we identified that discussed net neutrality from January to November 2014, there are a wide range of opinions on the merits of net neutrality regulations and the likely impact on innovation, democracy, economic growth, and investment in high-speed broadband infrastructure, along with many other angles.

As suggested by the top media sources shown earlier in Table 2, the link economy gravitated primarily to sources that either presented both sides of the debate, or came out in favor of net neutrality. This trend holds true when we look at the top stories, as shown in Table 13. Pro-net neutrality stories form the majority of the top stories, with John Oliver, President Obama, Netflix, and BattlefortheNet comprising the top four. Six of the top ten stories explicitly support neutrality, and nine of the top fifteen. Many of these are advocacy organizations who are strong proponents of net neutrality, e.g. Free Press, EFF, Fight for the Future, and Demand Progress. Among the top link recipients, the neutral stories are mostly from mainstream media with Wikipedia and the FCC also represented. 


\begin{tabular}{|c|c|c|}
\hline Title & Media Source & Inlinks \\
\hline Last Week Tonight with John Oliver: Net Neutrality & YouTube & 192 \\
\hline $\begin{array}{l}\text { President Obama's asking the FCC to keep the Internet open and } \\
\text { free }\end{array}$ & The White House & 151 \\
\hline Internet Tolls And The Case For Strong Net Neutrality & Netflix blog & 122 \\
\hline Battle For The Net & battleforthenet.com & 100 \\
\hline FCC to Propose New Net Neutrality Rules & Wall Street Journal & 98 \\
\hline Net neutrality & Wikipedia & 77 \\
\hline F.C.C., in a Shift, Backs Fast Lanes for Web Traffic & New York Times & 66 \\
\hline Free Press & Free Press & 57 \\
\hline Finding the Best Path Forward to Protect the Open Internet & FCC & 55 \\
\hline $\begin{array}{l}\text { This is why your Internet is slow. And it'll get worse. Unless you } \\
\text { take } 1 \text { min to do this, now. }\end{array}$ & battleforthenet.com & 55 \\
\hline Open Internet & FCC & 51 \\
\hline $\begin{array}{l}\text { What can we learn from } 800,000 \text { public comments on the FCC's } \\
\text { net neutrality plan? }\end{array}$ & Sunlight Foundation & 49 \\
\hline Protecting Net Neutrality and the Open Internet & Mozilla Policy \& Advocacy & 38 \\
\hline Goodbye, Net Neutrality; Hello, Net Discrimination & The New Yorker & 37 \\
\hline Save the Internet | Join the fight for Internet Freedom & savetheinternet.com & 36 \\
\hline Net Neutrality & savetheinternet.com & 34 \\
\hline FCC Net Neutrality Plan Calls for More Power Over Broadband & Wall Street Journal & 34 \\
\hline We the People: Your Voice in Our Government & The White House & 32 \\
\hline The Open Internet & FCC & 31 \\
\hline $\begin{array}{l}\text { The FCC is planning new net neutrality rules. And they could } \\
\text { enshrine pay-for-play. }\end{array}$ & Washington Post & 30 \\
\hline $\begin{array}{l}\text { Net Neutrality is Obamacare for the Internet; the Internet should } \\
\text { not operate at the speed of government. (Sen. Ted Cruz) }\end{array}$ & Twitter & 29 \\
\hline Appeals Court Strikes Down FCC's Net Neutrality Rules & Wall Street Journal & 28 \\
\hline VC Pitches In A Year Or Two & A VC & 28 \\
\hline Federal appeals court strikes down net neutrality rules & Washington Post & 26 \\
\hline Who Should Pay for Netflix? & AT\&T Public Policy Blog & 26 \\
\hline Comcast's deal with Netflix makes network neutrality obsolete & Washington Post & 25 \\
\hline Ensuring an Open Internet Now and for the Future & FCC & 25 \\
\hline Court strikes down FCC's net neutrality rules, agency may appeal & GigaOM & 24 \\
\hline DC Net neutrality ruling & Scribd & 24 \\
\hline Verizon statement on White House title II announcement & Verizon & 24 \\
\hline
\end{tabular}

Table 13. Inlinks by story 
Our qualitative read of coverage by traditional media is that it is generally down the middle, reporting the facts, presenting both sides of the argument, and citing sources from both sides. While the reporting of the Wall Street Journal coverage may tilt to the right, and the New York Times left, the distance between their coverage is generally modest. The coverage of the issue in tech media varies from taking a balanced approach, citing sources supporting and opposing net neutrality, to coverage that evinces explicit support for net neutrality and seeks to debunk claims made by broadband providers opposed to net neutrality. A few corporate actors that contributed to the debate also appear among the most linked-to stories: Netflix, a strong voice in favor of net neutrality; AT\&T and Verizon in opposition.

We have to travel far down the list to find views and voices opposed to net neutrality. The first example, 22nd on the list, is the tweet from Senator Ted Cruz: "Net Neutrality is Obamacare for the Internet; the Internet should not operate at the speed of government." However, it occupies this position only by virtue of the links it receives criticizing his position; none of the 29 inlinks are in clear support of his tweet. Verizon appears in 25th place with 26 inlinks to a November 10th story in opposition to Obama's statement; one of those 26 inlinks comes from an article that takes a clear anti-net neutrality stance. A blogpost from AT\&T in March responding to the Netflix blog post by Reed Hastings also received 26 inlinks; none of the inlinks come from anti-net neutrality articles. The next most highly ranked story in opposition is John Boehner's letter to Tom Wheeler, which is ranked 36th with 20 inlinks. None of the inlinks come from articles openly opposing net neutrality. A Comcast post on November 11th also received 20 inlinks explaining where the company and Obama agree (the Internet should be open) and disagree (reclassifying broadband providers under Title II). All of the links to this post come from neutral articles or supporters of net neutrality. An AT\&T blogpost from June 6th comes in at 100th with 11 inlinks, all of which come from neutral stories or those in the pro-net neutrality camp. Only at the very fringes of the link economy can one find evidence of like-minded organizations linking to opinions in opposition to net neutrality.

There are many strong voices in opposition to net neutrality from think tanks, ${ }^{27} \mathrm{blogs},{ }^{28}$ and media. ${ }^{29}$ None of them receive more than a few inlinks. DontBreaktheNet, sponsored by Tech Freedom, appears to

\footnotetext{
${ }^{27}$ http://www.heritage.org/research/reports/2014/02/net-neutrality-rules-still-a-threat-to-internetfreedom\#_ftn24 http://www.aei.org/publication/so-what-exactly-was-john-oliver-talking-about ${ }^{28} \mathrm{http}: / /$ www.redstate.com/diary/setonmotley/2014/03/31/lefts-ever-expanding-encompassing-net-neutrality/ http://hotair.com/archives/2014/11/10/an-era-of-compromise-deferred-obama-backs-liberal-wish-list-policy-ofnet-neutrality/ ${ }^{29} \mathrm{http}: / /$ www.sfgate.com/default/article/Don-t-make-the-Internet-a-public-utility-5478946.php
} 
be the anti-net neutrality campaign with the greatest number of inlinks. Of the 15 inlinks it receives, only two come from supportive sources: Cato.org and an article in Forbes written by Larry Downes. ${ }^{30}$ In the link economy, the only prominent platform for opponents of net neutrality is traditional media.

\section{Net Neutrality Links on Twitter}

Although the volume of traffic on Twitter was synchronized with general digital media (as shown earlier in Figure 2), we see in Table 14 that the most frequently linked-to sites on Twitter offer many differences compared to the results presented earlier drawing on a broader digital media landscape (Table 4).

BattlefortheNet is far and away the most frequently shared site on Twitter; links to this site were shared on Twitter more than the next eleven most-shared sites combined. Other popular sites shared frequently on Twitter include The Oatmeal, Netflix, John Oliver, President Obama, and a petition to the White House. This list is comprised largely of explicit calls to action: 16 of the top 25 promote action to support net neutrality. The number of mainstream media stories is far fewer. Except for four balanced stories, all of the top stories are in support of action on net neutrality. A Knight Foundation report shows similar results; the most retweeted messages in July and August were advocacy efforts in favor of net neutrality. ${ }^{31}$ Compared to the broader digital media landscape, Twitter appears to be used disproportionately more as a vehicle for social mobilization and less as a citation platform. In this instance, the mobilizing is heavily concentrated on the side of net neutrality.

\footnotetext{
http://dailycaller.com/2014/07/21/government-agency-that-wants-to-commandeer-the-internet-just-had-theirwebsite-crash-twice/ http://www.breitbart.com/big-government/2014/11/10/7-reasons-net-neutrality/ http://reason.com/archives/2014/11/12/net-neutrality-is-a-lousy-idea ${ }^{30} \mathrm{http}: / /$ dontbreakthe.net/ http://www.cato.org/blog/net-neutrality-or-destroying-internet-innovation-investment http://www.forbes.com/sites/larrydownes/2014/09/12/vcdc-when-internet-neutrality-principles-conflict-withengineering-everyone-loses/ ${ }^{31}$ http://www.knightfoundation.org/features/netneutrality/
} 


\begin{tabular}{|c|c|c|c|}
\hline Title & Media source & $\begin{array}{l}\text { Twitter } \\
\text { shares }\end{array}$ & $+/$ \\
\hline $\begin{array}{l}\text { This is why your Internet is slow. And it'll get worse. Unless you } \\
\text { take } 1 \text { min to do this, now. }\end{array}$ & BattlefortheNet.com & 131869 & \\
\hline Battle For The Net & BattlefortheNet.com & 43058 & \\
\hline $\begin{array}{l}\text { Dear Senator Ted Cruz, I'm going to explain to you how Net } \\
\text { Neutrality ACTUALLY works }\end{array}$ & The Oatmeal & 31920 & \\
\hline $\begin{array}{l}\text { If you hate this symbol, join Netflix and defend \#NetNeutrality on } \\
\text { Sept. 10th }\end{array}$ & Netflix & 23724 & \\
\hline Last Week Tonight with John Oliver: Net Neutrality & YouTube & 21720 & \\
\hline $\begin{array}{l}\text { President Obama's asking the FCC to keep the Internet open and } \\
\text { free }\end{array}$ & White House & 21505 & \\
\hline White House Petition: Maintain True Net Neutrality & White House & 13046 & \\
\hline Net Neutrality News, Videos, Reviews and Gossip & Gizmodo & 11185 & \\
\hline The Open Internet: A Case for Net Neutrality & theopeninter.net & 11031 & \\
\hline F.C.C., in a Shift, Backs Fast Lanes for Web Traffic & New York Times & 10997 & \\
\hline $\begin{array}{l}\text { White House Petition: Restore Net Neutrality By Directing the FCC } \\
\text { to Classify Internet Providers as "Common Carriers" }\end{array}$ & White House & 8999 & \\
\hline Net neutrality News, Videos, Reviews and Gossip & Kotaku & 7885 & \\
\hline *Everyone* at the FCC can help save net neutrality or destroy it. & CalltheFCC.com (EFF) & 7750 & \\
\hline Save the Internet | Join the fight for Internet Freedom & Savethelnternet.com & 7006 & \\
\hline Net Neutrality in the US: Now What? & YouTube: Vi Hart & 5875 & \\
\hline Net Neutrality: Join the Fight with Namecheap & NetNeutrality.com & 4816 & \\
\hline $\begin{array}{l}\text { Verizon using recent Net Neutrality victory to wage war against } \\
\text { Netflix }\end{array}$ & Davesblog.com & 4720 & \\
\hline Obama says FCC should reclassify internet as a utility & The Verge & 4371 & \\
\hline FCC approves plan to consider paid priority on Internet & Washington Post & 4359 & \\
\hline $\begin{array}{l}\text { President Obama's Statement on Keeping the Internet Open and } \\
\text { Free }\end{array}$ & YouTube & 4125 & \\
\hline Why Net Neutrality Matters (And What You Can Do To Help) & $\begin{array}{l}\text { YouTube: College } \\
\text { Humor }\end{array}$ & 3891 & \\
\hline $\begin{array}{l}\text { You Have Until Midnight to Yell at the FCC About Net Neutrality... } \\
\text { Sort Of }\end{array}$ & Gizmodo & 3866 & \\
\hline Last chance to save Net Neutrality & BoingBoing & 3649 & \\
\hline Internet Citizens: Defend Net Neutrality & You Tube: C.G.P. Grey & 3634 & \\
\hline Obama Calls for Strict Net Neutrality Policy & New York Times & 3590 & \\
\hline
\end{tabular}

Table 14. Links shared on Twitter 


\section{Clicks on Net Neutrality Stories via bit.ly}

Drawing on data from bit.ly, we can estimate which stories in the debate receive the most clicks on shortened URLs that have been shared via social media. This data serves as a proxy for the social media attention across a broader online audience. The overwhelming majority of clicks reported by bit.ly come from some combination of Twitter and Facebook.

\begin{tabular}{|c|c|c|c|}
\hline Title & Media source & $\begin{array}{l}\text { Bitly } \\
\text { clicks }\end{array}$ & $+/-$ \\
\hline Porn Stars Explain Net Neutrality & Funny or Die & 204678 & \\
\hline $\begin{array}{l}\text { The wrong words: how the FCC lost net neutrality and could kill the } \\
\text { internet }\end{array}$ & The Verge & 40474 & \\
\hline $\begin{array}{l}\text { Huge coalition led by Amazon, Microsoft, and others take a stand } \\
\text { against FCC on net neutrality }\end{array}$ & The Verge & 39775 & \\
\hline How the Net Neutrality Ruling Will Affect Your Netflix Habit & ABC News & 33113 & \\
\hline $\begin{array}{l}\text { This hilarious graph of Netflix speeds shows the importance of net } \\
\text { neutrality }\end{array}$ & Washington Post & 30942 & \\
\hline Maintain True Net Neutrality & White House petition & 25484 & \\
\hline Obama just announced his full support to preserve net neutrality & Mother Jones & 23771 & \\
\hline $\begin{array}{l}\text { This is why your Internet is slow. And it'll get worse. Unless you } \\
\text { take } 1 \text { min to do this, now. }\end{array}$ & battleforthenet.com & 23182 & \\
\hline $\begin{array}{l}\text { The FCC is about to axe-murder net neutrality. Don't get mad - get } \\
\text { even }\end{array}$ & Guardian & 20640 & \\
\hline $\begin{array}{l}\text { The FCC Just Approved A Proposal That Will Completely Change The } \\
\text { Internet As We Know It }\end{array}$ & Silicon Alley Insider & 20448 & \\
\hline $\begin{array}{l}\text { Netflix blasts Comcast and Verizon on net neutrality: 'some big ISPs } \\
\text { are extracting a toll' }\end{array}$ & The Verge & 19363 & \\
\hline $\begin{array}{l}\text { Dear Senator Ted Cruz, I'm going to explain to you how Net } \\
\text { Neutrality ACTUALLY works }\end{array}$ & The Oatmeal & 18941 & \\
\hline $\begin{array}{l}\text { Former Comcast and Verizon Attorneys Now Manage the FCC and } \\
\text { Are About to Kill the Internet }\end{array}$ & Vice & 18603 & \\
\hline The real battle for net neutrality just began & The Verge & 15669 & \\
\hline $\begin{array}{l}\text { Why you should be scared of the Comcast / Time Warner Cable } \\
\text { merger }\end{array}$ & The Verge & 14731 & \\
\hline $\begin{array}{l}\text { Google Fiber teams up with Netflix in fight against Comcast's } \\
\text { internet tolls }\end{array}$ & The Verge & 13846 & \\
\hline $\begin{array}{l}\text { AT\&T's Sponsored Data is bad for the internet, the economy, and } \\
\text { you }\end{array}$ & The Verge & 13552 & \\
\hline Your corporate internet nightmare starts now & The Verge & 12959 & \\
\hline Cable companies are astroturfing fake consumer support & Vice & 12365 & \\
\hline
\end{tabular}

Table 15. Bitly clicks by story 
We have to be cautious in interpreting this data as it does not accurately reflect readership of all stories in the debate. Not all media sources use bit.ly as a link shortener. For example, since YouTube does not use bit.ly, clicks on YouTube videos are not represented here. Another possible bias is that some sites promote sharing of their articles on social media via a mechanism that shortens links using bit.ly. As seen in Table 15, the Verge is particularly adept at getting users to share its stories on social media. We also note that this metric differs from the Twitter shared URLs metric in that it measures clicks on shared URLs rather than just the shares themselves.

This list offers a significantly different view of the media landscape. At the top of the list is a video by Funny or Die in which porn stars explain net neutrality. As a point of reference, this video is listed as having 2.8 million views on the Funny or Die site, and another 300,000 views on YouTube, compared to the 7.5 million views of the John Oliver video.

There are several familiar sites found in this list: a White House petition to maintain net neutrality and the BattlefortheNet site. Compared to the most shared links on Twitter, the stories with the most clicks via bit.ly are more often news reporting of the issue, likely reflecting common use of bit.ly URL shortening in share buttons on mainstream new sites. The list is also largely populated by stories that are supportive of net neutrality. Fourteen of the top twenty back net neutrality, the other six do not explicitly take either side.

Each of these data sets offers a different view of the media landscape, capturing different sets of users and different behavioral choices. While there are some common stories and media sources found across the top sites in Twitter, bit.ly, and the broader set of digital media, there are also interesting differences. A common feature that is unmistakable is the overwhelming support for enacting strong net neutrality rules (Figure 8). 


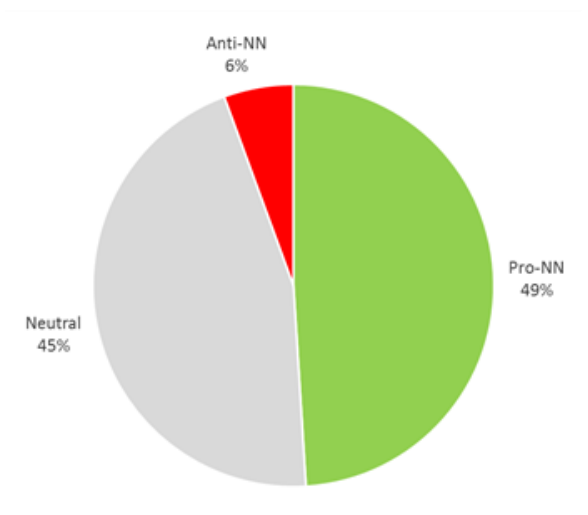

Inlinks

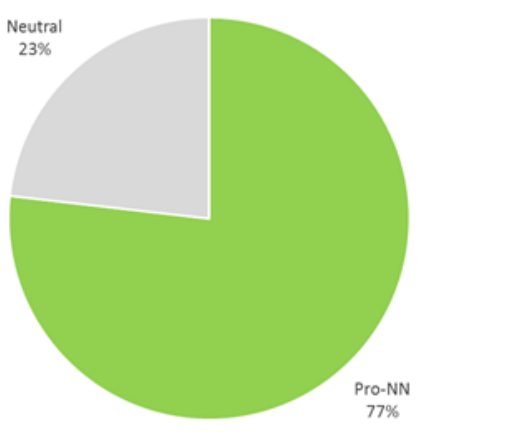

Bit.ly clicks

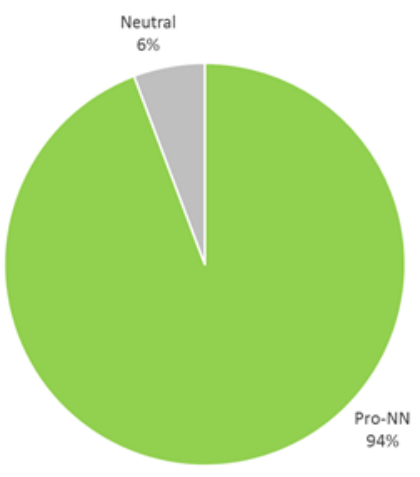

Twitter link shares

Proportion of inlinks to stories, bit.ly clicks on stories, and Twitter shares of stories supporting, opposing, or neutral to net neutrality. (Based on top 30 for each.)

Figure 8. Proportion of media stories that support, oppose, or take no position on net neutrality

\section{Discussion and Conclusions}

The debate in digital media over net neutrality is heavily skewed towards proponents of net neutrality. By every available measure - the link economy, social media sharing, and comments to the FCC - the balance of popular sentiment is clearly in support of taking decisive governmental action. Independent polling on the topic is rare but also shows public opinion overwhelmingly in support of net neutrality, with $81 \%$ saying they are opposed to allowing Internet service providers to charge websites or streaming 
video providers extra for faster speeds. ${ }^{32}$ In the net neutrality debate, we see a strong example that highlights the power and reach of networked collective action. The likely significant role of lobbying activity taking place behind closed doors makes any claims about the true extent and impact of the networked public sphere and digitally-mediated social mobilization on policy outcomes uncertain. Nevertheless, the available evidence suggests that civil society and non-traditional media activity played an instrumental and perhaps decisive role in turning around this debate.

The day after Wheeler's February $4^{\text {th }}$ announcement, the Wall Street Journal published a deep "insiders" story that suggested that the battle was primarily won by the CEOs of nimble startups Etsy, Tumblr, or Kickstarter and younger, more Internet-savvy White House staff, outmaneuvering not only Comcast, Time Warner, AT\&T, and Verizon, but also Google's Eric Schmidt's exhortations of the White House to side with the big companies on the question of net neutrality. ${ }^{33}$ The National Journal, by contrast, offered a more nuanced story, that combined both this inside story and a remarkable story of online social mobilization. Both stories focus on the fact that President Obama's speech on November $10^{\text {th }}$ was a turning point, and that it was likely influenced by the fact that the President had given up on working with congressional Republicans after their election victory, and was focusing on victories for his agenda that he could achieve without congressional cooperation. ${ }^{34}$ Both stories made it amply clear that Washington lawyer and long-time net neutrality fighter Marvin Ammori played a central role in orchestrating the startups' efforts with both Chairman Wheeler and the White House staff, and in explaining to them that reclassification was critical to Internet startups. How much of the President's ultimate decision was based on this insiders' game and the internal political consideration of a President seeking to make his legacy in the teeth of a hostile Capitol Hill is hard to gauge from publicly available data. One thing is apparent: by November the actions of millions of people online had made it abundantly clear that net neutrality was an area where assertive Presidential action would be embraced by millions of people willing to call their Senators and Representatives, file comments with the FCC Commissioners, sign petitions, and argue their case publicly. It would strain credulity to believe that the effect of the public mobilization involving millions of active participants online was completely overshadowed by the balancing of lobbying efforts by the cable and telephone industry versus the startups.

\footnotetext{
32 "National survey shows public overwhelmingly opposes Internet 'fast lanes, '" University of Delaware Center for Political Communication, November 10, 2014: http://www.udel.edu/cpc/research/fall2014/UD-CPCNatAgenda2014PR 2014NetNeutrality.pdf ${ }^{33} \mathrm{http}$ ://www.wsj.com/articles/how-white-house-thwarted-fcc-chief-on-internet-rules-1423097522 ${ }^{34}$ http://www.nationaljournal.com/tech/how-a-ragtag-band-of-activists-won-the-battle-for-net-neutrality20150205
} 
The dynamics of the SOPA-PIPA debate, which we analyzed in a prior study, offers a useful benchmark against which the debate and mobilization over net neutrality can be compared. In the SOPA-PIPA study, we point out that looking at the evolution of such controversies over time gives a more accurate depiction of the influence of different actors as it varies over time. We found that individual voices can indeed find an audience and impact debates and that the networked public sphere can raise the profile of experts and assess credibility. The role of alternative media, particularly tech media and campaign sites, were shown to have played critical roles in the debate. We also confirmed that the distinction between media and audience in agenda setting and framing has blurred, and that communication and action are increasingly inseparable. Finally, we found that the informed and politically engaged populace is not static; the public is indeed susceptible to being moved by current events and that networked advocacy can be effective at mobilizing segments of civil society that previously showed little or no interest in a topic. Despite the fact that the net neutrality debate differed from the SOPA-PIPA controversy in several important ways, all of these conclusions ring true in this study.

Unlike SOPA-PIPA, large media has provided consistent coverage of the issue. Nevertheless, the broader network of media actors was also active, tracking in broad strokes the experience of SOPA-PIPA. Tech media covered the controversy thoroughly and online advocacy campaigns inspired, coordinated, aggregated, and channeled individuals into coherent collection action. Specialized campaign sites coordinated by a network of advocacy organizations played a key role in instigating and aggregating public action. Compared to SOPA-PIPA, the role of tech media was perhaps less critical as mainstream media provided good coverage of the events as they unfolded and provided critical commentary and background information.

Individual and non-traditional voices were important actors in this debate. Parody and satire played a particularly strong role in communicating the issues, in promoting awareness, and in generating interest in a complex and highly technical issue. John Oliver, the Oatmeal, Funny or Die, and College Humor were all popular touch points in the outreach campaign. Individual experts are commonly cited in digital media. For example, Tim Wu's story in New Yorker is 15 th with 37 inlinks. His original paper receives 16 inlinks and he gets another 11 inlinks to his blog. Marvin Ammori gets 13 inlinks to a story in Wired, and two Ammori articles in Slate get 10 and 9 inlinks respectively with another 9 inlinks to his blog.

We again see the blurred distinction between media and audience in agenda setting, framing, and mobilization, and the integration of communication and action among civil society activists. There is no direct evidence to this effect, but the size of the civil society response suggests that activism efforts reached a significant number of people that otherwise would not have become involved. The inadvertent audience appears to live on. Just as we saw with gamers and tech-media followers in SOPA-PIPA, online 
media that are distinctly not political or aimed at a mobilized audience play a critical role, parallel in some senses to the role general-audience television was long hypothesized in political communications to play, of drawing in audiences removed from politics into the political.

The net neutrality issue is different from SOPA-PIPA in that the campaign was in support of a public policy initiative rather than seeking to prevent the passage of legislation with minimal public support. Given that the legislative arena is rich in veto points, it is much easier to block something in Congress than to move a regulatory agenda to adopt an affirmative policy.

SOPA-PIPA saw significant cross-partisan collaboration, with many on the right seeing the proposed law as overreaching regulation just as did many on the left. Net neutrality appears to be a more conventionally defined partisan issue. Public conservative voices are generally opposed to net neutrality; there is little evidence of prominent political figures crossing the aisle. SOPA-PIPA was an unusually bipartisan because strong enforcement of intellectual property online has long been a politically ambiguous category, with proponents and opponents on both sides of the political spectrum. The initial support and later opposition to the bills included both Democrats and Republicans. The widespread opposition to the legislation in the blogosphere was bipartisan as well. This is not true for net neutrality. The media coverage of this controversy appears to be divided cleanly across partisan lines. After reviewing coverage of conservative and liberal media sources, we found that the coverage in conservative media, blogs, and think tanks, the views were consistently in opposition to net neutrality. This includes coverage in the Washington Examiner, RedState, American Enterprise Institute, Breitbart, Daily Caller, the Blaze, the Heritage Foundation, Hot Air, and PJ Media. We similarly found liberal media to consistently support net neutrality, for example, in Slate, Salon, the Guardian, the Nation, the Atlantic, and Mother Jones. We also find that there are more liberal sources reporting on the issue than conservative sources.

It is unusual that a move towards greater government intervention would be so popular in the current political environment, suggesting that the issue has been successfully framed in terms other than big vs. small government. While conservatives saw net neutrality in terms of big-government/small-government, or excessive regulation, liberals saw it as a question of monopoly regulation and market power stifling innovation and free speech. One source of cross-over is among venture capitalists and entrepreneurs who along with net neutrality proponents fear that unregulated market power would squelch innovation, very much along similar lines to the arguments against SOPA-PIPA, with the privileged incumbents there being Hollywood, while the privileged incumbents here being the broadband providers. Another common depiction of the issue is oligopolistic corporations taking advantage of consumers with few market alternatives; a framing of the debate that does not neatly map onto traditional partisan lines. 
This campaign is in many ways more impressive than the campaign mounted in opposition to SOPAPIPA, a prior benchmark of effective digital activism, given the active, but to date ineffective, efforts by anti-net neutrality activists to influence the debate in the networked public sphere. The networked public sphere acted to filter and highlight different opinions on a complex topic. In this case, the public interest groups, policy experts, and academics that support net neutrality proved to be more credible sources of guidance on this issue; broadband providers failed to convince many that their arguments would well represent the interest of consumers. There is still room for debate over the merits of different approaches and there are well respected independent policy experts that have misgivings about government-mandated net neutrality. The overriding public sentiment on this issue is not in doubt. 